\title{
Studi Persepsi Mayarakat atas Pelayanan e-Toll di Kota Makassar
}

\section{Community Perception of e-Toll Services in Makassar City}

\author{
Amril Pratama Putra 1, Andi Gau Kadir ${ }^{2}$, Nurlinah ${ }^{3}$ \\ ${ }^{1}$ Administrasi Publik, Pasca Sarjana Fakultas Ilmu Sosial Dan Ilmu Politik, Universitas Hasanuddin, \\ Indonesia E-mail: amril.pratama7@gmail.com \\ 2 Ilmu Pemerintahan, Fakultas Ilmu Sosial Dan Ilmu Politik, Universitas Hasanuddin, Indonesia. \\ E-mail: gau_kadir@yahoo.com \\ 3 Ilmu Pemerintahan, Fakultas Ilmu Sosial Dan Ilmu Politik, Universitas Hasanuddin, Indonesia. \\ E-mail: nurlinah@yahoo.com
}

\section{ARTICLE INFO}

\section{Keywords:}

Transportation Service, Public Satisfaction,

Service Evaluation

Kata kunci: Pelayanan Transportasi, Kepuasan Pelanggan, Evaluasi Layanan

\section{How to cite:}

Putra, P. P., Kadir, A. G., \&, Nurlinah (2020) Studi Persepsi Masyarakat atas Pelayanan e-Toll di Kota Makassar. JAKPP (Jurnal Analisis Kebijakan dan Pelayanan Publik), 6(1), 86-100.

\section{ABSTRACT}

The government attempts to improve service quality of the transportation service sector, specifically on highways (toll roads) by imposing non-cash transaction payments. This policy aims to improve transactions efficiency and reduce traffic jam. This study aims to evaluate the non-cash payment policy, consumer perceptions and expectations in service on the-Toll road. The research method is a type of survey research with descriptive qualitative analysis. Respondents are 65 toll road users who were obtained using an online questionnaire. The results of the study explained that the majority of people were aware of this non-cash payment policy. However, the operation has not yet proceeded according to its purpose because there were still toll road users who failed the transaction because they did not carry a card or lack of balance. Public perception of the policy is very supportive, but the manager's service is low because he did not prepare a refill facility, but only provided a new card. The public hopes that toll road operators will continue to provide cash payment counters to anticipate transaction failures.

\begin{abstract}
Abstrak
Salah satu upaya pemerintah dalam sektor transportasi adalah peningkatan kualitas layanan transportasi di jalan bebas hambatan (jalan tol) dengan memberlakukan pembayaran transaksi nontunai. Kebijakan ini bertujuan untuk kemudahan transaksi dan efisiensi waktu transaksi. Penelitian ini bertujuan mengevaluasi kebijakan pembayaran non tunai, persepsi konsumen dan harapan dalam pelayanan di jalan tol. Metode penelitian adalah penelitian jenis survey dengan analisis sevara deskriptif kualitatif. Responden adalah pengguna jalan tol sebanyak 65 orang yang diperoleh dengan menggunakan kuisioner secara online. Hasil penelitian menjelaskan bahwa mayoritas masyarakat telah mengentahui kebijakan pembayaran non tunai ini. Namun dalam operasionalnya belum berjalan sesuai tujuan karena masih ditemukan penguna jalan tol yang gagal transaksi karena tidak membawa kartu atau saldo yang kurang. Persepsi masyarakat terhadap kebijakan sangat mendukung, namun menilai pelayanan pengelola rendah karena tidak
\end{abstract}


menyiapkan fasilitas pengisian ulang, namun hanya penyediaan kartu baru. Masyarakat berharap pengelola jalan tol tetap menyediakan loket pembayaran tunai untuk mengantisipasi gagal transaksi.

\section{Pendahuluan}

Peningkatan pelayanan transportasi menjadi salah satu fokus utama pemerintah Indonesia, baik di tingkat nasional maupun lokal. Layanan transportasi yang baik sangat berpengaruh pada peningkatan pembangunan ekonomi wilayah (Wetwito \& Kato, 2017; Novianti, 2013). Secara spesifik, studi yang dilakukan Dittmar (2019) mengungkap besarnya pengarus jalan bebas hambatan (jalan toll) pada percepatan pembangunan perdagangan dan manufaktur yang pada akhirnya berkontribusi besar pada pembangunan ekonomi.

Salah satu intervensi pemerintah dalam peningkatan layanan transportasi, khususnya di jalanan bebas hambatan adalah dengan memberlakukan tranksaksi non-tunai agar supaya mengurangi kemacetan di pintu tol. Kebijakan tersebut diatur dalam Peraturan Menteri Pekerjaan Umum dan Perumahan Rakyat (PUPR) Nomor 16/PRT/M/2017 tentang transaksi tol nontunai. Dengan diterapkannya pembayaran berbasis elektronik tersebut, memberi keuntungan bagi masyarakat pengguna jalan tol berupa pembayaran lebih praktis karena tidak perlu menyiapkan uang pas, kemudahan pembayaran dengan sistem tapping, tidak perlu lagi menyimpan uang kembalian dalam pecahan kecil, berkurangnya risiko salah jumlah uang kembalian, dan terhindar dari kemacetan di gerbang tol

Berdasarkan data BPS (2017), jumlah masyarakat yang melakukan transaksi secara tunai masih lebih besar yaitu $(89,7 \%)$ dibandingkan dengan yang bertransaksi secara non tunai yaitu (10,3\%). Uang elektronik (electronic money) atau lebih dikenal dengan e-money adalah uang yang digunakan dalam transaksi dengan cara elektronik. Adapun data Pengatur Jalan Tol (BPJT, 2018) pembayaran jasa tol melalui uang elektronik (E-Toll) telah mencapai 88 persen dari total transaksi pada awal Oktober. Hal ini sejalan dengan perencanaan pemerintah, BPJT, serta Bank Indonesia bahwa pembayaran jalan tol dengan menggunakan eToll sepenuhnya diberlakukan pada 31 Oktober 2017 di seluruh ruas jalan tol Indonesia. Namun kenyataan yang ditemukan, sampai batas waktu yang ditetapkan masih terdapat $92 \%$ pengguna jalan tol di Jabotabek dan $88 \%$ di luar Jabotabek (Bali, Makassar) menggunakan non tunai dengan total jumlah uang elektronik yang beredar 106,65 juta unit, yang diterbitkan oleh 27 perusahaan, 11 diantaranya berasal dari perbankan (Bank Indonesia, 2018).

Untuk mengetahui permasalahan yang terjadi dalam implementasi kebijakan pembelakukan non-tunai di jalan tol, penulis melakukan studi ini untuk mengetahui persepsi masyarakat terhadap layanan tersebut. 


\section{Kajian Literatur}

\section{Kebijakan Transportasi}

Transportasi umum adalah salah satu media transportasi yang digunakan masyarakat secara bersama-sama dengan membayar tarif. Menurut Papacostas (1987) dalam Adjisasmita (2014) transportasi didefinisikan sebagai suatu sistem yang terdiri dari fasilitas tertentu beserta arus dan sistem control yang memungkinkan orang atau barang dapat berpindah dari suatu tempat ke tempat lain secara efisien dalam setiap waktu untuk mendukung aktifitas manusia. Transportasi menjadi salah satu kebutuhan utama bagi masyarakat yang tidak mempunyai kendaraan untuk berpergian. Transportasi terbagi menjadi tiga komponen atau tiga jenis antara lain transportasi darat, transportasi laut, serta transportasi udara.

Pada era globalisasi ini saat ini sebagai negara berkembang Indonesia terus mengembangkan terobosan inovasi dalam meningkatan efisiensi dan efektivitas kinerja pada jalur pembayaran transportasi (Pambagio, 2014). Kartu yang ditawarkan berupa kartu elektrik untuk memudahkan penggunanya dalam bertransaksi. Dengan adanya kartu ini, perusahaan berharap dapat membantu mengurangi permasalahan di jalan tol. Saat ini operator tol yang bekerja sama yaitu Jasa Marga, Cipta Marga Nushapala Persada, Marga Mandala Sakti, dan Jalan tol Lingkar Luar Jakarta (JLJ). Manfaat utama pemegang kartu e-Toll adalah sebagai pengganti uang tunai.

Bank Indonesia selaku otoritas sistem pembayaran membagi dua jenis instrumen sistem pembayaran yaitu tunai dan non-tunai. Instrumen pembayaran tunai berupa uang kertas sebagai alat transaksi pembayaran memiliki banyak sekali keterbatasan sehingga tidak lagi dapat memenuhi kebutuhan masyarakat saat ini. Berbagai kebijakan dan pengembangan sistem pembayaran non tunai di tempuh Bank Indonesia dengan meluncurkan Gerakan Nasional Non Tunai (GNNT) dengan menggandeng pemerintah, perbankan, dan juga industri telekomunikasi, hal itu bertujuan agar masyarakat mulai mengurangi transaksi dengan menggunakan uang tunai.

Di Indonesia sendiri, e-money sudah ada pada tahun 2007, namun dengan kondisi infrastruktur di Indonesia, dibutuhkan waktu yang cukup lama agar masyarakat terbiasa menggunakan e-money. Meskipun e-money banyak memiliki manfaat dalam penggunaannya, masih banyak masyarakat yang beranggapan menggunakan uang tunai masih lebih mudah daripada menggunakan e-money. dapat dilihat pada diagram di bawah ini: 


\section{Diagram 1. Perbandingan Transaksi Tunai dan Non-Tunai di Indonesia}

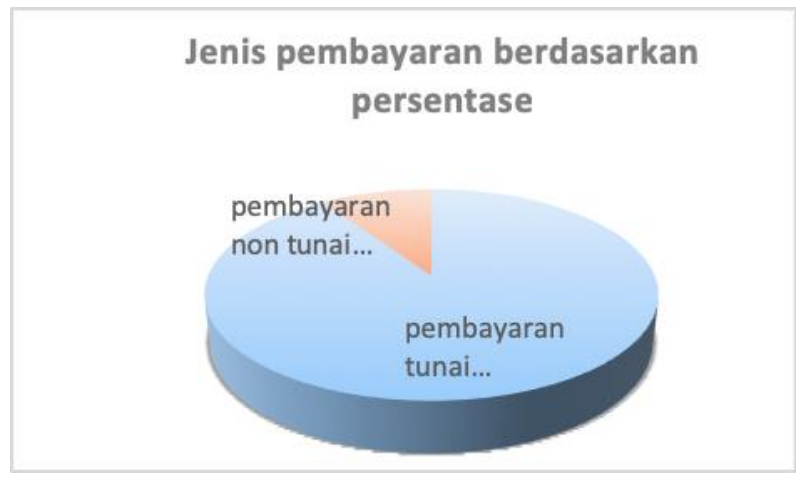

Sumber: Bank Indonesia, 2018

\section{Pelayanan Publik}

Salah satu tujuan dasar pemerintah adalah menyediakan pelayanan publik dengan kualitas terbaik atau dikenal dengan konsep pelayanan prima. Berbagai upaya dilakukan untuk meningkatkan pelayanan publik dengan mendesain kebijakan yang mendukung penyelenggaraan pemerintahan dan pembangunan daerah melalu peningkatan efisiensi, mutu dan efektifitas pelayanan (Umar, 2017).

Upaya lain dalam meningkatkan kualitas layanan publik adalah melalui kebijakan desentralisasi dan memberikan wewenang pemerintah daerah untuk meningkatkan kualitas layanannya di daerah. Dengan desentralisasi, maka pemerintah bisa lebih dekat dengan masyarakatnya serta memudahkan akses layanan publik ke masyarakat. Untuk itu, semua instansi pemerintah harus rencana strategi kelembagaannya dengan revitalisasi fungsi pelayanan aparatur pemerintah.

Pelayanan publik sangat erat kaitannya dengan pemerintah, karena salah satu tanggung jawab pemerintah ialah memberikan pelayanan kepada masyarakat. Kualitas pelayanan publik yang diterima masyarakat secara langsung dapat dijadikan tolak ukur dalam menilai kualitas pemerintah. Menurut Sinambela (2011) pelayanan publik diartikan sebagai pemberian layanan (melayani) keperluan orang atau masyarakat yang mempunyai kepentingan pada organisasi itu sesuai dengan aturan pokok dan tatacara yang telah ditetapkan.

Dalam rangka menjamin peningkatan kualitas layanan publik di semua sektor layanan, melalui Undang-undang No 25 tahun 2009 tentang pelayanan publik pemerintah di semua level diharuskan melakukan penilaian kepuasan kualitas pelayanan public. UU No 25 tahun 2009 mendefinisikan bahwa pelayanan publik adalah kegiatan atau serangkaian kegiatan dalam rangka pemenuhan kebutuhan pelayanan sesuai dengan peraturan perundang-undangan bagi setiap warga negara dan penduduk atas barang, jasa, dan atau pelayanan administratif yang disediakan oleh penyelenggara pelayanan publik. Kebijakan ini juga mengatur asas-asas pelayanan publik yang menjadi standar layanan prima semua pelayanan pemerintahan. Asas-asas pelayanan public tersebut adalah: kepentingan umum, kepastian hukum, kesamaan hak, keseimbangan hak dan 
kewajiban, keprofesionalan, partisipatif., persamaan perlakukan, keterbukaan, akuntabilitas, fasilitas, ketepatan waktu dan kecepatan.

\section{Persepsi Publik}

Masyarakat atau publik merupakan pengguna layanan yang disediakan pemerintah. Untuk itu, penilaian kualitas masyarakat atau persepsi public atas sebuah layanan menjadi acuan utama dalam mengukur derajat kesuksesan sebuah pelayanan. Oleh Walgito (2002) mendefenisikan persepsi merupakan suatu proses yang melibatkan proses pengindraan dan melahirkan stimulus individu dalam memberikan penilaian. Selanjutnya Walgito (2002) mengidentifikasi tiga indera utama yang melahirkan persepsi. Pertama, obyek melahirkan stimulus yang ditangkap oleh alat indera atau reseptor. Stimulus bisa saja datang dari luar individu seperti lingkunga sekitar. Namun juga muncul dalam internal individu sendiri. Kedua, Indera yang terdiri atas susunan syaraf alat indera atau reseptor yang berfungsi dalam menerima stimulus. Selanjutnya, indera dengan syaraf sensornya mengirimkan pesan kepada otak sebagai pusat informasi dan susunan kesadaran manusia. Otak sebagai kemudian mengirimkan reaksi berdasarkan pengalaman untuk mengambil tindakan melalui motoris yang dapat membentuk persepsi seseorang. Terakhir, perhatian merupakan langkah utama dalam menyusun dan melahirkan persepsi. Perhatian lahir dengan memusatkan pikiran atau konsentrasi dari semua kegiatan individu untuk ditujukan ke sejumlah obyek.

Selanjutnya, studi ini mengidentifikasi beberapa definisi persepsi. Oleh Kottler dan Keller (2009) menerjemahkan "persepsi adalah proses seorang individu memilih, mengorganisasikan dan menafsirkan masukan-masukan informasi untuk menciptakan suatu gambaran yang bermakna tentang dunia". Demikian halnya dengan Kanuk (2007) yang menguraikan syarat lahirnya persepsi, yaitu: 1) Penerimaan pesan atau informasi dari luar. 2) Memberikan kode pada informasi yang diindera. 3) Menginterpretasikan informasi yang telah diberikan kode tersebut. 4) Menyimpulkan arti dalam ingatan.

Selanjutnya Thoha (2008) dalam Hari et al, (2013) menjelaskan beberapa faktor-faktor yang mempengaruhi persepsi seseorang yaitu faktor internal berupa perasaan, sikap dan kepribadian individu, prasangka, keinginan atau harapan, perhatian (fokus), proses belajar, keadaan fisik, gangguan kejiwaan, apresiasi, nilai dan kebutuhan juga minat, apresiasi, dan motivasi. Adapun faktor eksternal berupa latar belakang keluarga, informasi yang diperoleh, pengetahuan dan kebutuhan sekitar, intensitas, ukuran, keberlawanan, pengulangan gerak, hal-hal baru dan familiar atau ketidak asingan suatu objek.

Berdasarkan beberapa pendapat para ahli tersebut dapat ditarik kesimpulan bahwa syarat-syarat terjadinya persepsi adalah adanya objek fisik (objek dapat dirasakan, dicium, diraba, didengar sehingga menimbulkan stimulus), syarat 
fisiologis (adanya alat indera, saraf sensorik dan otak), dan syarat psikologis (adanya perhatian dari individu sehingga dapat menyadari apa yang diterima).

\section{Metode Penelitian}

Penelitian ini menggunakan metode gabungan kualitatif fan kuantitatif. Alasan peneliti menggunakan metode kuantitatif karena persepsi publik harus didapatkan melalui menanyakan langsung persepsi setiap warga atau pengguna layanan terhadap layanan pembayaran non-tunai di tol. Metode kuantitatif dilakukan melalui survei. Peneliti juga melakukan kualitatif untuk mendapatkan informasi langsung dari pengelola jalan tol melalui wawancara.

Penelitian ini dilaksanakan pada bulan Mei sampai Juni 2019 di Kota Makassar, Provinsi Sulawesi Selatan. Penentuan lokasi secara purposive sampling.

Sumber data terdiri dari data primer dan data sekunder. Data primer adalah data pokok yang bersumber dari hasil wawancara dan pengamatan langsung kepada informan. Survei dilakukan melalui daring dengan membagikan tautan di media sosial. Peneliti berhasil mendapatkan 65 responden yang mengisi angket daring ini. Selain itu, peneliti juga melalukan wawancara dengan pengelola tol untuk mendapatkan informasi terkait pelaksanaan dan pelayanan serta ketersediaan fasilitas dalam melayani pelanggan jalan toll.

Penelitian ini akan mengevaluasi kebijakan tentang penggunaan e-Toll dengan mendapatkan data dari pengguna dan pengelola jalan tol. Data yang terkumpul dianalisis dengan statistik deskriptif.

\section{Hasil dan Pembahasan}

\section{Perbedaan dengan penelitian sebelumnya}

Pada penelitian ini ada 4 penelitian yang djadikan pembanding. Dari keempat penilitian diatas dapat di tarik kesimpulan perbedaan dengan penelitian ini adalah dalam hal objek kajiannya. Kesamaan pada objek Kebijakan Publik. Namun fokus berbeda. Pada penelitian sebelumnya terkait transportasi membahas implementasi kebijakan terkait wilayah operasi Bus Damri (Oktaviani (Oktavianti \& Lituhayu, 2017; Putri et al., 2015). Dan yang lainnya membahas persepsi masyarakat terhadap pelayanan di Kantor (Atmodjo, 2014; Bannu dan Slamet, 2013). Penelitian tentang persepsi dan tingkat kepuasan terhadap kebijakan e-toll merupakan penelitian yang masih baru karena penerapan e-toll baru dioptimalkan di Tahun 2018.

\section{Gambaran Umum responden}

\section{a. Umur dan Jenis kelamin}

Responden penelitian ini terdiri atas 67,7\% laki laki dan 32,3\% perempuan. Usia responden terbanyak adalah antara 25 sampai 45 tahun pada laki laki $(30,7 \%)$ 
dan perempuan (17\%). Data ini menggambarkan bahwa penguna jasa jalan toll berada pada usia produktif dan di dominasi jenis kelamin laki laki.

\section{b. Pendidikan dan Pekerjaan}

Data latar pendidikan responden umumnya adalah SMA $(38,3 \%)$, D3/S1 $(28 \%)$, S3 (7,6\%). Hal ini menggambarkan bahwa informasi terkait tujuan penelitian akan tercapai karena responden memiliki pemahaman yang cukup luas akan suatu kebijakan. Selain itu dengan pendidikan yang cukup maka masukan masukan terkait peningkatan pelayanan di jalan toll akan lebih baik. Adapun pekerjaan terbanyak adalah PNS (43,2\%) dimana laki-laki $(30,7 \%)$ dan perempuan $(12,5 \%)$. Besarnya jumlah PNS ternyata ada kaitannya dengan data tentang alasan mereka menggunakan jalan tol, yaitu ke bandara mengantar atau menjemput tamu. Selanjutnya pekerjaan sebagai karyawan swasta $(35,5 \%)$ terdapat juga $(10,5 \%)$ responden bekerja sebagai wirausaha yang menggunakan jalan tol karena ada urusan bisnis, seperti kebandara atau ke daerah diluar kota Makassar

\section{c. Frekuensi dan alasan menggunakan jalan tol}

Frekuensi responden yang menggunakan jalan tol yang terbanyak adala pengguna jalan yang tidak tetap $(61,5 \%)$ yang melewati jalan tol karena ada hal tertentu saja misalnya menghindari kemacetan, mengantar tamu kebandara atau akan keluar daerah. Pengguna tol setiap bulan (17\%), setiap minggu (13.8\%), dan setiap hari $(7,7 \%)$. Adapun alasan menggunakan jalan tol yaitu ke bandara $(38,4 \%)$, Ke tempat kerja $(35,3 \%)$ dan akan keluar daerah $(17 \%)$. Responden yang menggunakan jalan tol ketempat kerja adalah yang bekerja di wilayah Maros, Pangkep atau disekitar tol.

\section{Kebijakan Pembayaran Non Tunai}

Peraturan Menteri Pekerjaan Umum dan pwrumahan Rakyat (PUPR) Nomor 16/PUPR/M/2017 yang mengatur pembayaran non tunai di gerbang tol membutuhkan waktu untuk implementasinya. Hal ini terkait dengan perubahan prilaku pengendara di jalan bebas hambatan yang sebelumnya terbiasa membayar dengan menggunakan tunai. Berdasarkan observasi peneliti, implementasi kebijakan pembayaran tol dengan non tunai belum bisa diberlakukan sepenuhnya. Peneliti menemukan masyarakat pengguna jalan toll yang belum siap mengunakan non tunai. Untuk itu peneliti melihat pengelola tol melakukan sosialisasi untuk mengajak pengguna tol pelan-pelan beralih ke pembayaran nontunai. Terdapat tiga strategi utama pengelola tol untuk melakukan proses transisi prilaku tersebut, yaitu:

(1). Membuat spanduk, billboard tentang penggunaan $e$-Toll pada berbagai titik yang mudah di akses masyarakat sebelum memasuki jalan tol

(2). Menyiapakan petugas di gerbang toll untuk membantu pelanggan dalam menggunakan mesin $e$-Toll 
(3). Menyiapkan kartu e-Toll bagi pengguna jalan yang tidak memiliki atau saldonya tidak mencukupi.

Hal ini sejalan dengan apa yang disampaikan oleh Informan AM (42 tahun) yang merupakan petugas pengelola jalan tol:

"kami berusaha memberikan pelayanan yang terbaik, dengan menyiapkan petugas di setiap gerbang pembayaran, karena memahami kalau masih ada konsumen yang lupa atau tidak memiliki saldo cukup dalam bertransaksi."

Upaya pemerintah untuk meningkatkan pelayanan di gerbang toll Makassar dengan memperbaiki fasilitas dan pelayanan. Sepanjang $17 \mathrm{~km}$. Dengan system pembayar e-Toll yang terus di tingkatkan, maka tahun 2108 pendapatan yang diterima mencapai 490 juta perhari. Adapun fasilitas yang disiapkan pengelola tol reformasi melalui PT Bosowa Marga Nusantara adalah disiapkannya kendaraan mobil derek, mobil Patroli Jalan Raya (PJR), mobil ambulans dan mobil pengawas yang siaga selama 24 jam, yang diberikan secara gratis. Oleh sebab itu yang dibutuhkan konsumen adalah nomor kontak dari pengelola jalan tol. Untuk mengoptimalkan pelayanan pada konsumen maka tol reformasi Makassar juga telah memiliki alat deteksi dibeberapa titik yang langsung terpantau di monitor kantor pusat BMN Makassar.

\section{Persepsi Pengguna Jalan Tol Terhadap Penggunaan e-Toll}

Persepsi merupakan penilaian penggunan layanan jalan tol mengenai kualitas layanan yang disediakan.

\section{a. Pemahaman terhadap Kebijakan pembayaran non tunai}

Persepsi pengguna jalan tol dari aspek pemahamannya terhadap kebijakan pemerintah dalam hal pembayaran non tunai atau kartu e-Toll/Kartu UNIK terkait pengetahuan mereka akan suatu objek. Pada grafik 1 ditunjukkan pemahaman responden terhadap kebijakan pembayaran non tunai sebagai berikut 


\section{Grafik 1. Jumlah dan Persentase Pemahaman Responden Terhadap Kebijakan Pembayaran Non Tunai}

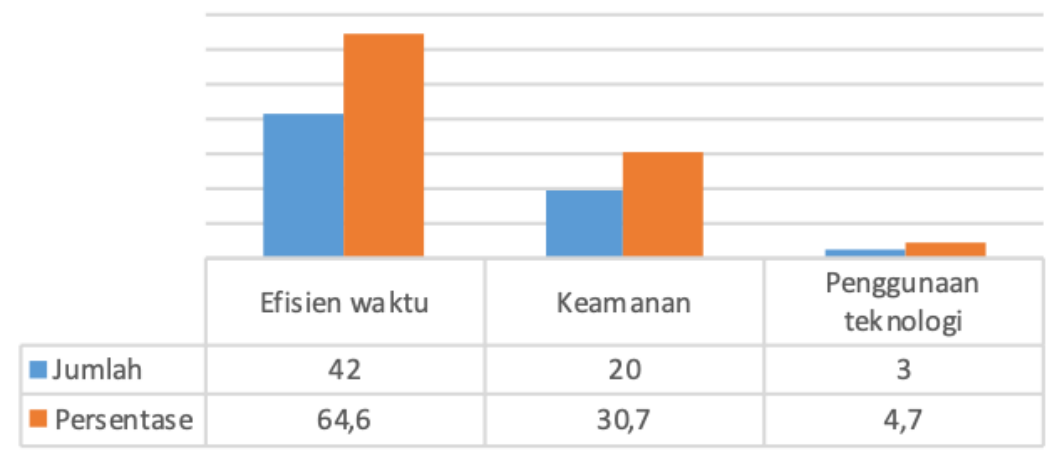

Sumber : Data Primer diolah 2019

Pada grafik 1 menunjukkan ada tiga pemahaman responden terhadap kebijakan pembayaran non tunai, masing masing dari yang terbesar adalah memahami bahwa kebijakan ini bertujuan untuk mengefisenkan waktu bagi pengguna jalan $(64,6 \%)$, memberi rasa keamanan karena pembayaran tidak menggunakan uang tunai $(30,7 \%)$ dan yang memahami bahwa kebijakan ini adalah gambaran dari perkembangan teknologi dalam hal penggunaan uang non tunai $(4,7 \%)$. Dari hasil analisis ini dapat di simpulkan bahwa responden memiliki pemahaman yang positif pada kebiajakan pemerintah terkait pembayaran non tunai di jalan tol Makassar. Data ini juga menunjukkan bahwa mayoritas responden melihat manfaat utama dari pembayaran non-tunai adalah untuk mengefisienkan waktu. Hal itu tentu sangat sesuai dengan tujuan kebijakan ini. Dengan demikian dapat dikatakan bahwa potensi untuk pemanfaatan kartu e-Toll di Kota Makassar akan berjalan sesuai harapan pemerintah.

\section{b. Respon terhadap kebijakan pembayaran non tunai}

Menurut Mar'at (1982), menyatakan bahwa respon seseorang terhadap obyek akan berhubungan dengan pengetahuan, pengalaman, cakrawala, keyakinan, dan proses belajar. Respon yang diberikan responden terkait kebijakan pembayaran non tunai di tol Makassar sangat baik dimana yang sangat mendukung $(29,2)$ dan mendukung $(61,4 \%)$, yang bernakna bahwa kebijakan ini mendapat dukungan karena dinilai memberikan manfaat yang lebih baik dari pada dengan penggunaan dana tunai (Cash). Hal ini menggambarkan bahwa pengguna jalan tol memang sudah membutuhkan sentuhan teknologi, khususnya terkait dengan efisisensi dalam pembayaran. Belajar dari pengalaman pembayaran tunai, pengendara umumnya harus menyiapkan uang pas apabila tidak ingin menunggu proses pengembalian yang dilakukan secara manual. Selanjutnya yang merespon dengan menilai kebijakan ini cukup (9,6\%) karena meragukan teknologi ini dapat dilakukan oleh semua pengguna jalan tol yang 
beragam karakter dan pendidikan Sebagai mana dapat dilihat pada grafik 52 berikut:

Grafik 2. Jumlah dan Persentase Responden Terhadap Kebijakan $e$-Toll

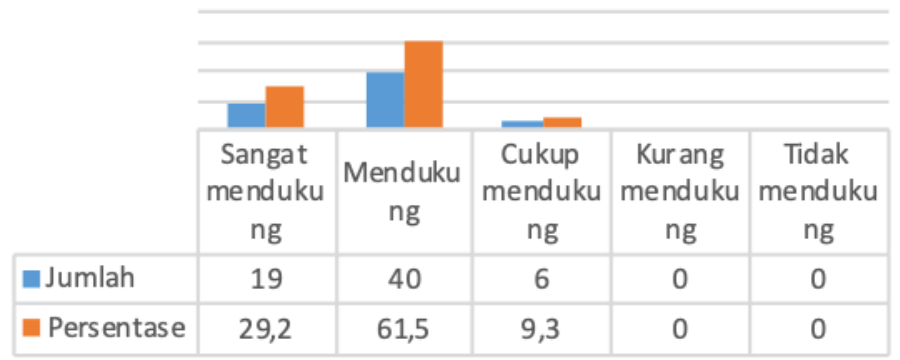

Sumber : Data primer diolah 2019

Berdasarkan data maka perlukan pendekatan dengan memberi kesempatan terjadinya proses perubahan prilaku masyarakat dari kebiasaan pembayaran tunai menjadi non tunai. Salah satu bentuk yang dapat dilakukan adalah dengan menyiapkan fasilitas pembayaran non tunai bagi pengguna jalan tol yang tidak membawa atau saldonya tidak mencukupi untuk beberapa waktu tertentu.

\section{Harapan Responden}

Harapan adalah keinginan seseorang terhadap suatu objek, Harapan biasanya menggambarkan adanya kondisi yang lebih baik dari sebelumnya. Pada bahasan terkait harapan responden dari adanya kebijakan pembayaran non tunai di tol menunjukkan perlunya ada upaya pengelola untuk lebih meningkatkan pelayanan.

\section{a. Harapan terhadap kartu e-Toll}

Ada empat harapan responden terkait kartu e-Toll yaitu (1). Kemudahan mendapatkan kartu (2). Kemudahan Melakukan top up (3). Tersdianya kartu di gerbang tol dan (4) Ada petugas yag siap di gerbang tol. Dari ke lima harapan tersebut maka harapan terbesar adalah kemudahan dalam melakukan top up $(44,8 \%)$ dan kemudahan mendapatkan kartu (30,7\%). Besarnya harapan responden terhadap kemudahan melakukan top up menunjukkan bahwa ada pengalaman pengguna jasa jalan tol dalam melakukan top up yang kurang sesuai dengan harapan mereka. Kondisi ini sesuai dengan penjelasan responden pada kuisioner yang menjelaskan pengalaman gagal transaksi karena saldo tidak cukup di gerbang tol, tidak dapat dilakukan dengan top up dan petugas hanya bisa menawarkan kartu baru. Akibatnya terdapat $63,3 \%$ responden yang memiliki lebih dari 2 kartu $e$-Toll. 


\section{b. Harapan terhadap fasilitas Jalan tol}

Fasilitas jalan tol yang terkait dengan penggunaan kartu e-Toll adalah berfungsinya mesin otomatis, karena salah satu tujuan untuk mempersingkat perjalanan. Menurut pengelola jalan tol transaksi dengan menggunakan kartu hanya memerlukan waktu 2 sampai 3 detik, dibanding secara tunai sekitar 2 sampai 4 menit. Oleh sebab itu fungsi mesin otomatis sangat besar.

Mengacu pada data responden yang memiliki kartu lebih dari 1 umumnya karena gagal transaksi Adapun penyebab gagal transaksi ditunjukkan pada grafik 3 berikut:

\section{Grafik 3. Jumlah dan Persentase Respponden yang Pernah Gagal Transaksi}

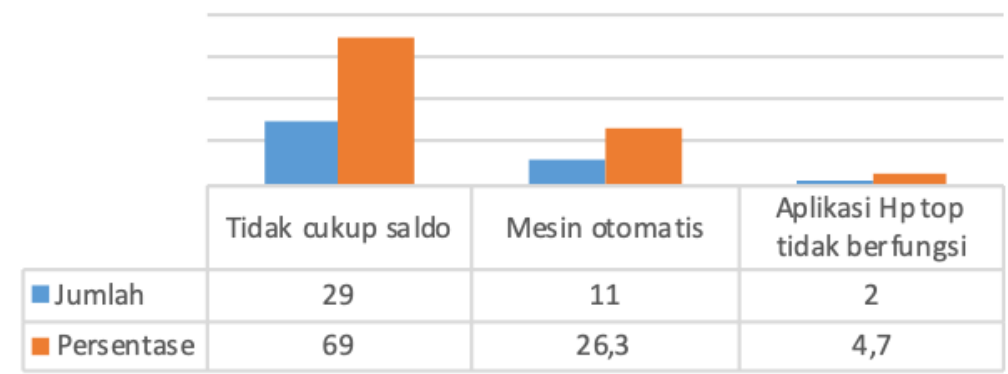

Sumber: Data primer diolah 2019.

Dari grafik 3 menggambarkan bahwa gagal transaksi disebabkan oleh tidak cukupnya saldo (69\%), dan gagal dalam melakukan aplikasi top up melalui aplikasi HP (4,7\%) dan terdapat (26,3\%) karena mesin otomatis tidak berfungsi atau lamban merespon kartu e-Toll.

Kegagalan akibat mesin otomatis memiliki dampak yang cukup besar bagi upaya untuk mengoptimalkan pemanfaatan kartu e-Toll. Hal ini ditunjukkan dari harapan responden terhadap kebijakan penggunaan kartu dalam hal memilih apakah tetap disiapkan pembayaran tunai bagi pengguna jasa jalan tol, yang ditunjukkan pada grafik 4 berikut:

\section{Grafik 4. Jumlah dan Persentase Harapan Responden Terhadap Pelayanan} e-Toll

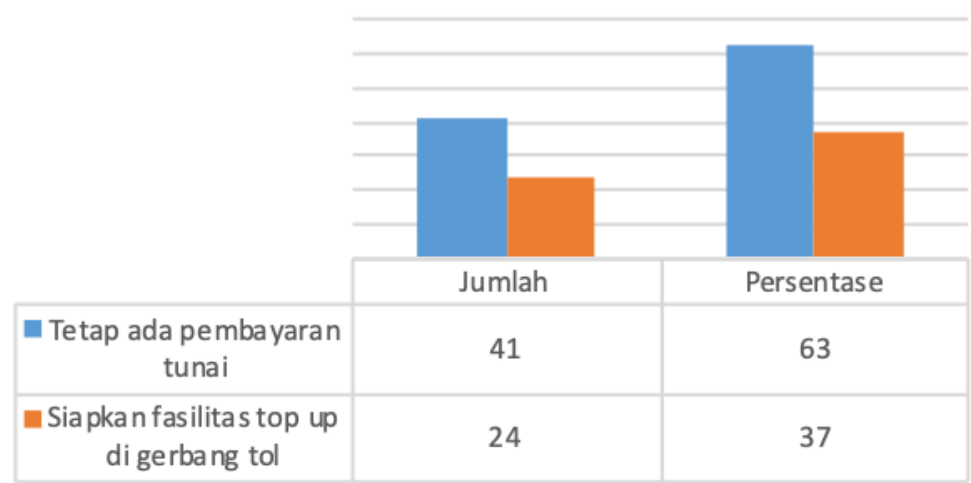

Sumber: Data Primer diolah 2019. 
Pada grafik 4 menggambarkan harapan responden untuk tetap disiapkan pembayaran tunai (63\%) cukup besar hal ini dimaksudkan agar dapat mengantisipasi kekurangan saldo kartu e-Toll atau pengguna jalan tol tidak membawa kartu. Hal ini menunjukkan bahwa pengguna jasa jalan tol masih perlu di fasilitasi untuk mengimplementasikan kebijakan pembayaran non tunai. Hal ini memberi gambaran bahwa pemerintah masih perlu bekerja keras untuk menyadarkan masyarakat bukan hanya menggunakan kartu e-Toll tetapi lebih pada kesadaran untuk membawa dan mencukupi saldo setiap memasuki jalan tol.

\section{c. Harapan terhadap pengelola jalan tol}

Harapan pengguna pada petugas jalan tol lebih pada pelayanan dalam hal kesiapan membantu pengguna yang mengalami permasalahan. Sebagai contoh permasalahan dalam melakukan top up, yang selama ini tidak ditemukan di gerbang tol, petugas hanya menawarkan kartu baru akibatnya pengguna menambah kartu lagi dan saldo yang tersisa tidak dapat dimanfaatkan.

Harapan lainnya dari responden adalah tersedianya rest space/atau tempat istirahat bagi pengguna jalan $(15,4 \%)$, harapan ini mengingat ada pengguna jasa jalan tol yang mengalami keletihan atau mengalami ganggguan kesehatan saat mengemudi. Lebih jelasnya pada grafik 5 ditunjukkan harapan harapan responden pada pengelola jalan tol.

\section{Grafik 5. Jumlah dan Persentase Harapan Responden pada Pengelola Jalan Tol}

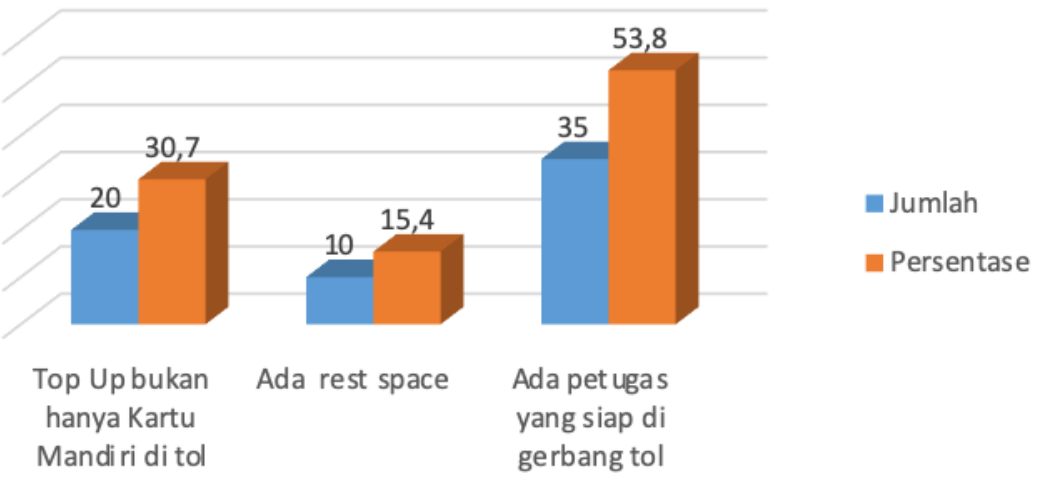

Sumber : Data Primer diolah 2019

Pada grafik 5 memperjelas harapan responden terhadap pengelola jalan tol berupa kesiapan petugas digerbang tol. Kondisi ini terkait dengan masih besarnya jumlah pengguna jalan tol yang tidak membaa kartu atau saldo kartu yang tidak mencukupi, sehingga adanya petugas akan sangat membantu. Meskipun pada penjelasan sebelumnya ditemukan bahwa petugas tidak dapat melakukan top up, tetapi hanya menawarkan kartu baru. Kondisi inilah yang 
hendaknya diperbaiki oleh pengelola jalan tol agar kepuasan konsumen dapat dipenuhi.

\section{Kesimpulan}

Kebijakan pemerintah yang tertuang pada Peraturan Menteri Pekerjaan Umum dan Perumahan Rakyat (PUPR) Nomor 16/PRT/M/2017 tentang transaksi tol non tunai yang mulai diterapkan Tahun 2017 belum berjalan sesuai rencana. Penggunaan kartu $e$-Toll telah menunjukkan peningkatan namun dalam operasionalnya, masyarakat masih membutuhkan adanya pembayaran non tunai karena masih pengguna jalan tol yang tidak membawa kartu atau saldo kartu tidak mencukupi. Adapun persepsi dan harapan pada kebijakan menunjukkan sangat mendukung, namun masih perlu peningkatan pelayanan dalam hal pengisian ulang atau top up, yang selalu siap ditiap pintu gerbang. Harapan lainnya adalah masih tetao disiapkan pembayran tunai, dan menyediaakn rest area bagi pengguna jalan tol, yang kelelahan agar terhindar dari kecelakaan.

\section{Saran}

Beberapa saran sebagai masukan pada pemerintah terkait pelaksanaan kebijakan pembayaran non tunai $e$-Toll

1. Masih diperlukan upaya sosialisasi kebijakan pembayaran non tunai e-Toll kemasyarakat terkait kesiapan kartu dan saldo yang cukup mengingat penguna jasa tol umumnya bukan pengguna tetap.

2. Fasilitas top up hendaknya dapat dilakukan pengguna jasa jalan tol. karena selama ini yang disiapkan pengelola tol hanya kartu baru. Akibatnya Konsumen memiliki lebih dari satu kartu.

3. Kebutuhan penggguna jalan tol terhadap ketersediaan ruang singgah/ Rest area menjadi penting karena adanya peluang pengguna jalan keletihan atau mengalami gangguan kesehatan dan berakibat pada kecelakaan

\section{Daftar Pustaka}

Adisasmita, Sakti Adji (2014) Perencanaan Transportasi, Tangerang: Universitas Terbuka

Bank Indonesia (2018) Laporan Perekonomian Indonesia 2018, Jakarta: Bank Indonesia

Badan Pusat Statistik (2017) Kajian Aktual Dampak Pelaksanaan Transaksi Non Tunai Terhadap Efisiensi Belanja Daerah, Jakarta: Badan Pusat Statisik

BPJT (Badan Pengelola Jalan Tol (2018) 5 Jalan Tol dengan Volume Lalu Lintas Tertinggi Tahun 2017, http://bpjt.pu.go.id/berita/5-jalan-tol-denganvolume-lalu-lintas-tertinggi-tahun-2017 
Bannu, Herbasuki dan Slamet (2013) Implementasi Kebijakan Transportasi Jalan Tol Sumatera. Jurnal Transportasi 8(2): 23-50

Dittmar H. (2019) Highway Capital and Economic Productivity: In My Kind of City. Washington, DC: Island Press,

Hari, Idris, Adam, Burhanuddin (2013) Persepsi masyarakat Terhadap pelayanan Publik di kantor Kecamatan Kutai Kartanegara . eJournal Administrative Reform, 2013, 1 (1): 287-301

Pambagio, Agus (2014) Protes Publik Transportasi Indonesia, Jakarta: Gramedia

Novianti, Diah (2013) Pemberdayaan Angkutan Umum Sebagai Salah Satu Faktor Penting Dalam Keberhasilan Pembangunan. Jurnal Cakrawala, 8(1):43-50

Oktavianti, Dinar Rizki dan Lituhayu, Dyah (2017) Implementasi Kebijakan Transportasi Umum di Kota Semarang (Studi kasus Perum Damri), Journal of Public Policy and Management Review, 6(3):1-11

Putri, Esti Hartyanti, Soeady, Moch. Saleh, dan Hayat, Ainul (2015) Evaluasi Kebijakan Peremajaan Angkutan Kota Dalam Upaya Peningkatan Pelayanan Publik (Studi Pada Dinas Perhubungan Kota Malang). Jurnal Administrasi Publik, 3 (1):87-93

Atmodjo, Idrus Chairiansyah (2014) Evaluasi kebijakan Transportasi Dalam Rangka Mengurangi Kemacetan di Jakarta. Jurnal Administrasi Publik, 2(8)

Kadarisman, Muhammad, Gunawan, Aang dan Ismiyati (2015) Implementasi Kebijakan Sistem Transportasi darat dan Dampaknya Bagi Kesejahteraan Sosial, Jurnal managemen Transportasi dan Logstik, Vol 2 (1):59-78

Kottler, Philip dan Keller, Kevin L. (2009) Marketing Management, New York:Pearson

Umar, Zulkarnain (2017) Analisis Implementasi Kebijakan Standar Pelayanan Mininal Untuk Peningkatan Kualitas Layanan Publik di Daerah, Jurnal Analisis Kebijakan dan Pelayanan Publik, 3(1):1-13

Wetwitoo, Jetpan \& Kato, Hironori (2017) Inter-regional Transportation and Economic Productivity: A Case Study of Regional Agglomeration Economies in Japan, The Annals of Regional Science, 59: 321-344

Widodo, Joko. 2009. Analisis Kebijakan Publik. Malang : Banyumedia Winarno, Budi. 2012.

\section{Peraturan perundang undangan}

Undang-undang No. 14 Tahun 1992 tentang LLAJ

Peraturan Pemerintah Nomor 15 Tahun 2005 tentang Jalan tol

Undang -undang Nomor 25 Tahun 2009 tentang Kebijakan Publik 
Volume 6 No. 1, Juni 2020

pISSN: 2460-6162. eISSN: 2527-6476

Undang-undang Nomor 23 Tahun 2014 tentang Pemerintah Daerah

Peraturan Menteri Pekerjaan Umum Dan Perumahan Rakysat Nomor 16/PRT/M/2017 Tahun 2017. Tentang pembayaran e-Toll 